\title{
BAHAN BELAJAR MANDIRI SEBAGAI SUATU MODEL MODUL STUDI ISLAM BERWAWASAN DERADIKALISASI PEMAHAMAN AGAMA
}

\author{
Susanto \\ e-mail: susanto_kpai@yahoo.com \\ Komisi Perlindungan Anak Indonesia (KPAI)
}

Jl. Teuku Umar No. 10-12 Menteng Jakarta Pusat

\begin{abstract}
Abstrak:Penelitian pengembangan model modul belajar mandiri studi Islam berwawasan deradikalisasi pemahaman agama ini bertujuan untuk meningkatkan kemampuan mahasiswa memahami ajaran Islam tanpa radikalisme. Penelitian ini dilakukan di Fakultas Sains dan Teknologi UIN Jakarta, mulai Januari 2012 - November 2015. Penelitian pengembangan diawali dengan penelitian pendahuluan mengikuti model Borg \& Gall, selanjutnya langkah-langkah pengembangan produk mengikuti prosedur model pengembangan instruksional (MPI) dengan produk akhir, dalam bentuk modul belajar mandiri. Hasil uji validasi, produk pengembangan telah dilakukan secara benar sesuai prosedur yang dipedomani, mulai tahap mengidentifikasi, mengembangkan dan mengevaluasi serta merevisi. Untuk menguji efektifitas produk pengembangan, peneliti menggunakan dua cara, yaitu menilai respon pengguna dan uji t. Pada hasil dari uji coba efektifitas ditemukan fakta bahwa modul telah efektif meningkatkan kemampuan mahasiswa dalam menggunakan metode memahami ajaran Islam tanpa radikalisme.
\end{abstract}

Kata-kata Kunci; modul, bahan belajar mandiri, deradikalisasi

\section{SELF-LEARNING MATERIAL AS A MODEL OF ISLAMIC STUDY MODUL WITH THE CONCEPT OF RELIGION UNDERSTANDING DERADICALISM}

\begin{abstract}
The research development model of Islamic study self-learning module with religion understanding de-radicalization is to improve students' ability to understand the teachings of Islam without radicalism. The study began with the development of a preliminary study following the model by Borg \& Gall, then the product development followed the procedures of instructional development model (MPI) resulting the final product in the form of self-study module. The validation test and product development were carried out properly according to the procedures, starting from identifying, developing and evaluating and revising. To test the effectiveness of product development, the researcher used two techniques of assessing user's response and $t$-test. The results of the effectiveness test show that the module has effectively improved the students' ability to use the methods of understanding the Islam teachings without radicalism.
\end{abstract}

Keywords: module, self-study materials, de-radicalization, product development

\section{PENDAHULUAN}

Radikalisme atas nama agama, saat ini sudah sampai pada tahap membahayakan, bukan saja mengancam fondasi kebangsaan, namun juga mengancam lembaga pendidikan. Lingkungan kampus menghadapi tantangan besar terkait radikalisme atas nama agama. Rekrutmen jaringan faham keagamaan radikal tampaknya terjadi di sejumlah perguruan tinggi, UI, ITB, IPB, UNPAD, UGM, bahkan UIN Jakarta, terutama fakultas non keagamaan. Menurut hasil sejumlah penelitian dan pengakuan pelaku yang keluar dari sel-sel radikal dan ekstrem mengisyaratkan, mahasiswa perguruan tinggi umum dan fakultas umum lebih rentan terhadap rekrutmen daripada mahasiswa perguruan tinggi berbasis agama.

Kerentanan mahasiswa terhadap radikalisme atas nama agama dewasa ini cukup serius. Apalagi, penyemaian ideologi radikalisme semakin dinamis, bukan saja berlangsung melalui saluran-saluran konvensional, namun juga melalui self-indoctrinization dengan memanfaatkan informasi dari laman-laman daring yang membuat mahasiswa mengalami radikalisasi dengan sendirinya.

Mahasiswa Fakultas Sains dan Teknologi UIN Jakarta, mengalami kerentanan terhadap radikalisme. Riset CSRC UIN Syarif Hidayatullah Jakarta kerentanan radikalisme di kalangan mahasiswa Sains dan Teknologi mencapai 22,2\% (Pranawati, 2012: 134-138). Kondisi tersebut menjadikan Perguruan 
Tinggi dewasa ini menghadapi tantangan besar dalam memainkan peran strategisnya, terutama dalam menghadapi gejolak radikalisme atas nama agama. Terjadinya serangkaian kekerasan agama terhadap kelompok minoritas, ekstrimisme pemahaman agama, intoleransi antar umat beragama, tindakan terorisme, berkembangnya kelompok pengusung ideologi negara Islam Indonesia (NII) disinyalir terus melakukan rekruitmen anggota dengan melakukan cuci otak, menjadi ancaman serius bagi bangsa ke depan terutama mahasiswa (Ghafur, 2014: 1).

Radikalisme berasal dari kata "radikal" yang merupakan turunan kata dari "radix" artinya akar, pangkal, bagian bawah dan juga bsia berarti menyeluruh, habis-habisan, amat keras untuk menuntut perubahan (Rapik, 2014: 107-108). Sementara, menurut Jamaluddin (2015: 1) radikalisme berasal dari kata radic yang berarti akar dan radikal adalah (sesuatu) yang bersifat mendasar atau 'hingga ke akar-akarnya'. Predikat ini bisa dikenakan pada pemikiran atau paham tertentu, sehingga muncul istilah 'pemikiran yang radikal' dan bisa pula 'gerakan' atau "tindakan".

Berdasarkan pendapat di atas, dapat dipahami bahwa radikalisme mengandung dua makna yang kontradiktif, ada yang memaknai positif yaitu pemikiran, ideologi atau tindakan yang mendasar, namun ada juga yang memaknai negatif yaitu radikalisme diidentikkan dengan intimidasi, kekerasan dan teror. Pemaknaan terakhir cenderung menjadi faktor dominan terjadinya kekerasan atas nama agama yang merusak sendi-sendi kehidupan keagamaan dan kebangsaan.

Menurut Qardhawi sebagaimana dikutip Yurisaldi (2011: 11) seseorang dapat dikatakan sebagai radikal, jika memenuhi kriteria sebagai berikut; pertama, seseorang yang fanatik kepada suatu pendapat, tanpa menghargai pendapat lain dan tidak membuka pintu dialog untuk orang lain. Orang mengklaim pendapatnya paling benar dan mengatakan pendapat keagamaan orang lain sebagai sesat. Kedua, mewajibkan orang lain untuk melakukan apa yang tidak diwajibkan oleh Allah SWT. Seseorang yang radikal cenderung memaksa orang lain agar melakukan ibadah sunnah sebagaimana wajib. Ketiga, melakukan sikap keras yang tidak pada tempatnya. Keempat, memiliki sikap keras dan kasar. Maksud point ini adalah keras dalam berdakwah dan kasar dalam bergaul. Kelima, selalu berburuk sangka kepad aorang lain, sehingga tertutup kebaikan-kebaikan yang ada dalam diri orang lain, yang ada hanyalah keburukan-keburukan saja. Keenam, mengkafirkan orang lain. Radikalisme mencapai puncaknya ketika menggugurkan kesucian orang lain serta menghalalkan darah dan harta.

Secara faktual radikalisme atas nama agama, tampaknya tidak mengekspresikan dalam bentuk perilaku tunggal, selain menggunakan cara-cara kekerasan fisik (direct violence), juga terlihat dalam bentuk ekspresi kebencian dan penghinaan (AlQurtuby, 2009: 11). Kedua tipologi tersebut, berdampak negatif bagi perguruan tinggi dan masyarakat luas.

Idealnya perguruan tinggi memainkan peran kongkrit dalam mencegah kerentanan mahasiswa dari ancaman radikalisme atas nama agama melalui deradikalisasi pemahaman agama. Terlebih, pendidikan tinggi berfungsi mengembangkan kemampuan, watak, dan kepribadian manusia. Konsekuensinya, seluruh proses penyelenggaraan pendidikan di perguruan tinggi berorientasi pada pengembangan kepribadian mahasiswa yang berkeadaban bukan pribadi yang radikal, karena radikalisme atas nama agama merupakan bentuk penyimpangan perilaku yang harus dicegah.

Menurut Omar Ashour (2009: 3), deradicalisation is abother process of relative change within islamist movements, one in which a radical group reverses its ideology and de-legitimises the use of violent methods active political goals, while also moving towards an acceptance of gradual social, political and economic changes within pluralist context.

Menurut ROL sebagaimana dikutip Fikri (2013: 270) deradikalisasi adalah upaya untuk meluruskan penafsiran yang salah terhadap ajaran Islam, terutama tentang jihad. Nasaruddin Umar (2014: 4) berpandangan bahwa deradikalisasi bukan dimaksudkan sebagai upaya untuk menyampaikan pemahaman baru tentang ajaran Islam dan bukan pula pendangkalan akidah, melainkan sebagai upaya meluruskan dan mengembalikan tentang apa dan bagaimana Islam.

Berdasarkan definisi tersebut diatas dapat dipahami bahwa deradikalisasi merupakan upaya meluruskan, menetralisir dan merubah pandangan, pemahaman, keyakinan atas ajaran Islam yang melekat pada seseorang atau kelompok agar terjadi perubahan pemahaman atau perubahan perilaku yang positif.

Penelitian Pengembangan Bahan Belajar Mandiri Sebagai Suatu Model Modul Studi Islam Berwawasan Deradikalisasi Pemahaman Agama sangat penting dikarenakan; (1), tertangkapnya sejumlah mahasiswa yang teridentifikasi sebagai pengikut jaringan terorisme, menunjukkan adanya masalah penyelenggaraan pendidikan, sehingga 
diperlukan solusi; (2), Mata Kuliah Pengantar Studi Islam yang diperoleh mahasiswa belum relevan untuk pencegahan radikalisme atas nama agama; (3), jaringan radikalisme atas nama agama melakukan berbagai strategi untuk menjadikan kalangan mahasiswa, sebagai target group, sehingga membentengi mahasiswa dari radikalisme suatu keniscayaan; (4), mahasiswa dalam proses mencari jati diri dan haus akan informasi, diperlukan sumber belajar belajar yang mampu mencegah kerentanan radikalisme atas nama agama; (5), Fakultas Sains dan Teknologi UIN Jakarta belum memiliki model deradikalisasi atas nama agama.

Penelitian pengembangan bahan belajar mandiri dalam bentuk modul Studi Islam berwawasan deradikalisasi pemahaman agama sangat penting, mengingat; (1), berdasarkan hasil penelitian pendahuluan modul studi Islam telah tersedia, namun modul yang memiliki content deradikalisasi pemahaman agama belum tersedia; (2), dari sisi pengguna, modul belajar mandiri, fleksibel, cukup praktis dan mudah digunakan serta tidak membutuhkana alat bantu lain; (3), membelajarkan pengguna, mengingat modul tidak hanya berisi uraian materi, namun juga penugasan mandiri.

Atas fakta tersebut, penelitian pengembangan ini dilakukan untuk mendapatkan model modul yang dapat meningkatkan kemampuan mahasiswa dalam memahami ajaran Islam tanpa radikalisme.

Fokus masalah penelitian ini meliputi; (1), bagaimana upaya pencegahan radikalisme atas nama agama bagi mahasiswa yang telah berjalan di Fakultas Sains dan Teknologi UIN Syarif Hidayatullah Jakarta?; (2), Bagaimana model perancangan bahan belajar mandiri studi Islam yang berwawasan deradikalisasi pemahaman agama?; (3), Bagaimana merancang modul bahan belajar mandiri studi Islam berwawasan deradikalisasi pemahaman agama?; (4), Apakah modul bahan belajar mandiri studi Islam berwawasan deradikalisasi pemahaman agama yang telah dirancang dapat meningkatkan kemampuan mahasiswa memahami ajaran Islam tanpa radikalisme?

Penelitian diharapkan dapat berguna secara teoritis maupun praktis, meliputi: (1), kegunaan Ilmiah. Model modul studi Islam berwawasan deradikalisasi pemahaman agama dapat memberikan kontribusi ilmiah bagi teknologi pendidikan, studi Islam dan pengembangan model deradikalisasi pamahaman agama; (2), kegunaan praktis. Model modul studi Islam berwawasan deradikalisasi pemahaman agama dapat menjadi masukan Kementerian Riset, Teknologi dan Pendidikan Tinggi RI., dan Kementerian Agama RI untuk menangkal radikalisme pemahaman agama yang dewasa ini mengancam kalangan mahasiswa di perguruan tingi; (3), dalam tataran implikasi, dengan diterapkannya model modul studi Islam berwawasan deradikalisasi pemahaman agama, dapat membekali mahasiswa untuk membentengi diri dari arus radikalisme atas nama agama, baik secara pribadi, kelompok maupun institusi.

Selama ini telah banyak penelitian deradikalisasi agama, namun bukan melalui model pengembangan bahan belajar, seperti; Islamist Radicalisation: A Root Cause Model karya Tinka Veldhuis \& Jørgen Staun diterbitkan oleh Netherlands Institute of International Relations Clingendael, 2009. Kemudian Racism \& Extremism Monitor Deradicalisation in Practice karya Froukje Demant, Willem Wagenaar dan Jaap van Donselaar, diterbitkan oleh Liden University, 2009.

Sementara penelitian di Indonesia umumnya terkait radikalisme agama, bukan deradikalisasi agama. Sebagaimana hasil penelitian Lembaga Kajian Islam dan Perdamaian (LAKIP) yang melibatkan 590 dari total 2.639 guru Pendidikan Agama Islam (PAI) dan 993 siswa Muslim dari total 611.678 murid SMA se-Jabodetabek berkesimpulan sebanyak 62.7 $\%$ responden guru PAI terinfiltrasi radikalisme pemahaman agama.

Secara umum tujuan penelitian pengembangan ini menghasilkan modul bahan belajar mandiri studi Islam berwawasan deradikalisasi pemahaman agama. Secara khusus, tujuan penelitian ini adalah; (1), mengidentifikasi upaya pencegahan radikalisme pemahaman agama yang telah berjalan di Fakultas Sains dan Teknologi UIN Syarif Hidayatullah Jakarta; (2), menghasilkan model perancangan bahan belajar mandiri studi Islam yang berwawasan deradikalisasi pemahaman agama; (3), merancang modul bahan belajar mandiri studi Islam yang berwawasan deradikalisasi pemahaman agama; (4), menguji efektifitas modul bagi peningkatan kemampuan mahasiswa dalam memahami ajaran Islam secara komprehensif untuk mencegah radikalisme.

\section{METODE PENELITIAN}

Penelitian ini menggunakan penelitian dan pengembangan (research and development) mengacu kepada model Borg \& Gall (Gall, 1983: 775). Prosedur penelitian Borg and Gall, memiliki 10 langkah sebagai berikut: (1) penelitian dan pengumpulan informasi, (2) perencanaan, (3) pengembangan produk, (4) 
uji lapangan awal, (5) revisi produk utama, (6) uji lapangan lanjut, (7) revisi produksi operasional, (8) uji lapangan operasional, (9) uji lapangan akhir, dan (10) diseminasi dan implementasi.

Penggunaan model Borg \& Gall hanya untuk langkah penelitian pendahuluan, selanjutnya prosedur pengembangan modul belajar mandiri dirancang mengikuti langkah-langkah MPI. Secara sederhana proses penelitian pengembangan dapat diuraikan sebagai berikut; model prosedural mengikuti langkahlangkah Model Pengembangan Instruksional (MPI), yang terdiri dari tiga tahap (1), tahap mengidentifikasi; (2), tahap mengembangkan; (3), tahap mengevaluasi dan merevisi, (Suparman, 2012: 156). Sebelum tiga tahapan dalam model prosedural dilaksanakan, terlebih dahulu dilakukan penelitian pendahuluan dari Borg \& Gall.

Selanjutnya, kerangka berfikir modul belajar mandiri berwawasan deradikalisasi pemahaman agama dijiwai oleh The Fifth Discipline dari Senge (2000: 59-93) yaitu berpikir sistem, personal mastery, mental model, visi bersama dan team learning. Kelima dimensi dari Peter Senge tersebut dipadukan secara utuh untuk mewarnai kerangka berfikir pengembangan bahan belajar mandiri studi Islam berwawasan deradikalisasi pemahaman agama.

Penelitian ini dilakukan di Fakultas Sains dan Teknologi UIN Jakarta, mulai Januari 2012 - November 2015. Metode pengumpulan data dalam penelitian pendahuluan menggunakan teknik wawancara, observasi dan studi dokumen. Data dianalisis melalui reduksi data, penyajian data dan penarikan kesimpulan. Data hasil penelitian pendahuluan digunakan sebagai dasar analisis kebutuhan. Hasil analisis kebutuhan kemudian dijadikan pijakan untuk pengembangan produk instruksional melalui beberapa langkah meliputi; mengidentifikasi, mengembangkan, mengevaluasi dan revisi produk.

Sementarauntukmenguji produkpengembangan menggunakan uji ahli desain instruksional, ahli materi dan ahli bahasa. sedangkan uji coba produk menggunakan uji one to one, uji kelompok kecil serta uji lapangan. Hasil validasi dan uji coba digunakan untuk revisi produk pengembangan, agar layak digunakan untuk belajar mandiri.

\section{HASIL DAN PEMBAHASAN}

Hasil penelitian pendahuluan ditemukan bahwa mahasiswa Fakultas Sains dan Teknologi UIN Jakarta rentan radikalisme atas nama agama. Indeks radikalisme mahasiswa bahkan mencapai
22,20\%. Namun demikian, upaya pencegahan radikalisme pemahaman agama yang telah berjalan di lingkungan mahasiswa masih lemah, sumber belajar yang berwawasan deradikalisasi pemahaman agama belum tersedia, mata kuliah yang ada belum relevan. Berdasarkan analisis kebutuhan, mahasiswa membutuhkan modul bahan belajar mandiri studi Islam berwawasan deradikalisasi pemahaman agama.

Berdasarkan kajian pustaka, membandingkan model pengembangan yang tersedia, kemudian peneliti memilih Model Pengembangan Instruksional (MPI) sebagai acuan pengembangan bahan belajar mandiri. Pada kedua langkah MPI yaitu menyusun strategi dan pengembangan bahan instruksional diintegrasikan pemikiran The Fifth Discipline dari Peter Senge, mulai berpikir sistem, belajar tuntas, model mental, visi bersama serta belajar beregu. Kelima dimensi dari Peter Senge tersebut dipadukan secara utuh untuk mewarnai kerangka berpikir pengemasan dan strategi dalam bahan belajar mandiri studi Islam.

Setelah menetapkan MPI sebagai model pengembangan pembelajaran yang tepat untuk mengembangkan modul belajar mandiri, maka prosedur pengembangannya melalui 3 langkah, yaitu: tahap identifikasi, tahap mengembangkan, tahap mengevaluasi dan merevisi.

Model yang dikembangkan terdiri atas (1) model konseptual; (2) model prosedural, dikembangkan mengikuti prosedur MPI. Dalam pengemasan bahan dan strategi instruksional dijiwai oleh kerangka berpikir Fifth Discipline Peter Senge; (3) model fisikal, dalam bentuk modul, panduan dosen dan CD petunjuk latihan mandiri bagi mahasiswa.

Untuk mengetahui efektifitas produk, uji coba lapangan merupakan keharusan. Hal ini peneliti lakukan setelah mendapatkan validasi dan rekomendasi tim pakar bahwa produk dinyatakan layak. Gambaran efektifitas hasil uji coba lapangan akan terlihat dari kebergunaan dan kebermanfaatan model yang dikembangkan. Manifestasi dari kebergunaan dan kebermanfaatan model yang dikembangkan adalah terlihat dari dua faktor yaitu (1) tanggapan subjek uji coba, serta (2) perbandingan hasil nilai pretest dan posttest.

Hasil uji coba efektifitas produk melalui tanggapan subyek sebagai berikut. Pertama, uji coba perorangan meliputi; (a), kejelasan materi pembelajaran; (b), dampak bagi pengguna; (c), kelayakan dan sikap pengguna. Tanggapan subjek terhadap ketiga indikator ditunjukkan dalam gambar 1 berikut. 


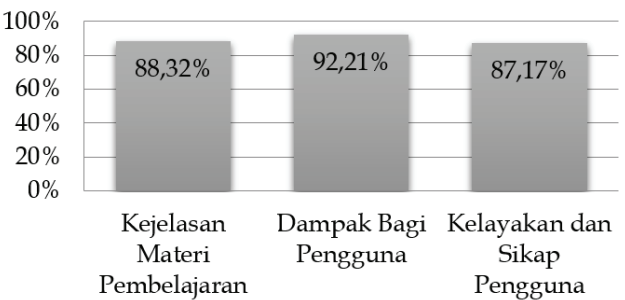

Gambar 1. Grafik hasil uji coba perorangan

Secara keseluruhan kualitas tanggapan subyek uji coba perorangan terhadap indikator kelayakan dan sikap pengguna berada pada rerata 4,54 atau $89,23 \%$. Dapat disimpulkan bahwa modul belajar mandiri studi Islam berwawasan deradikalisasi pemahaman agama sudah layak dan dapat digunakan.

Kedua, uji coba kelompok kecil. Hasil yang diperoleh dari ujicoba dari kelompok kecil (small group) meliputi: (1) kemenarikan modul, (2) durasi waktu pembelajaran, (3) penguasaan materi pembelajaran, (4) kesesuaian penggunaan ilustrasi, (5) kesesuaian evaluasi dengan materi. Tanggapan terhadap indikator-indikator tersebut dapat terlihat dalam gambar 2 .

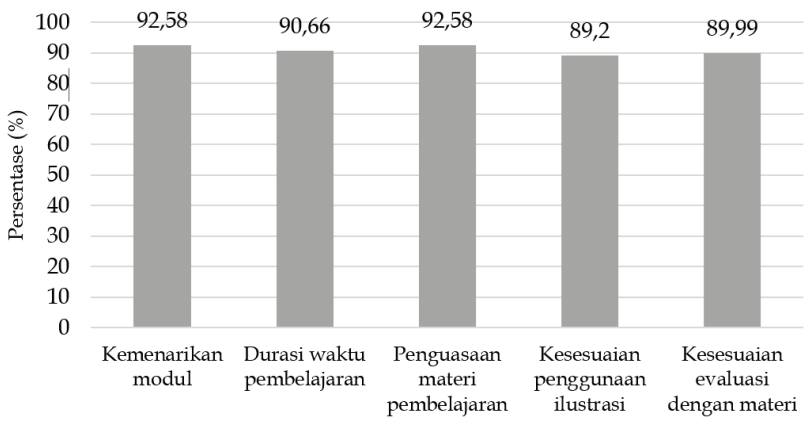

Gambar 2. Grafik hasil uji coba kelompok kecil

Secara keseluruhan, keterterimaan subyek uji coba kelompok kecil terhadap modul belajar mandiri studi Islam berwawasan deradikalisasi pemahaman agama, yang telah dikembangkan rata-rata 4,54 atau $91,00 \%$. Dengan demikian, dapat simpulkan bahwa modul belajar mandiri studi Islam berwawasan deradikalisasi pemahaman agama sudah layak sebagai sumber belajar.

Ketiga, uji coba lapangan. Hasil yang diperoleh dari uji coba lapangan meliputi: (1) sikap pembelajar terhadap produk pengembangan, (2) kelayakan produk pengembangan, (3) kemutakhiran materi produk pengembangan. Gambaran tanggapan subyek uji coba dapat dicermati dalam gambar 3 .

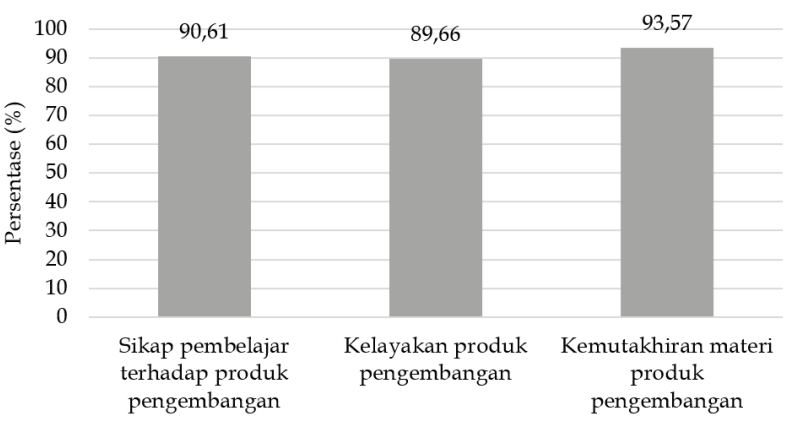

Gambar 3. Grafik hasil uji coba lapangan

Secara keseluruhan kualitas tanggapan subyek uji coba lapangan terhadap penerimaan dan kebergunaan modul berada pada rata-rata 4,54 atau $91,28 \%$. Berdasarkan hasil uji coba tersebut dapat disimpulkan bahwa modul belajar mandiri studi Islam berwawasan deradikalisasi pemahaman agama sudah layak dan dapat digunakan. Dari gambaran uji coba, sudah mencerminkan ciri-ciri pengguna akhir dari modul yang dikembangkan.

Dengan hasil penilaian dimaksud, menunjukkan bahwa modul belajar mandiri studi Islam berwawasan deradikalisasi pemahaman agama efektif dan layak digunakan sebagai sumber belajar baru bagi mahasiswa. Gambaran dari keseluruhan uji efektifitas disajikan dalam gambar 4.

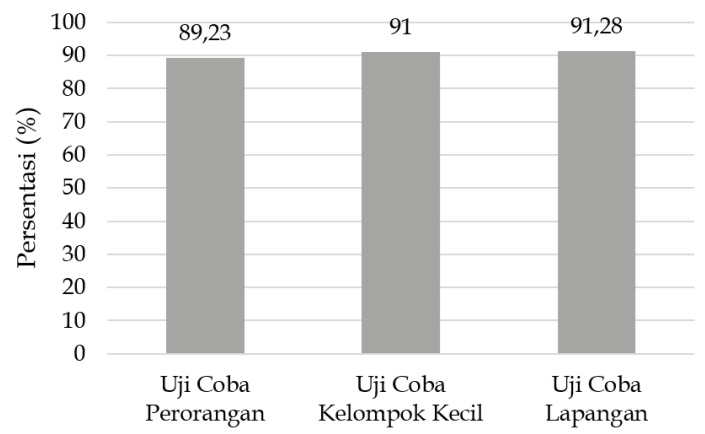

Gambar 4. Grafik hasil uji efektifitas

Grafik 4 menggambarkan bahwa tingkat penerimaan subyek uji coba pada tiga tingkatan berada pada kategori sangat baik. Uji coba perorangan mencapai $89,23 \%$, selanjutnya Uji coba kelompok kecil 91,00\% sementara uji coba lapangan 91,28\%. Hasil tersebut menunjukkan bahwa produk pengembangan modul belajar mandiri studi Islam berwawasan deradikalisasi pemahaman agama sudah efektif, dapat diterima dan dapat digunakan sebagai sumber belajar baru bagi mahasiswa.

Selain secara kualitatif, dalam uji lapangan ini dilakukan secara kuantitatif. Kegiatan yang 
dilakukan adalah menerapkan belajar mandiri dengan menggunakan produk final kepada sampel yakni mahasiswa baru Fakultas Sains dan Teknologi UIN Syarif Hidayatullah Jakarta sebanyak 27 orang. Pelaksanaan uji lapangan terhadap sampel dari berbagai program studi di lingkungan Fakultas Sains dan Teknologi UIN Syarif Hidayatullah Jakarta. Sebelum mahasiswa melakukan belajar mandiri dengan menggunakan modul yang telah dikembangkan, dilakukan tes awal (pretest) dan pada akhir belajar mandiri dilakukan tes akhir (posttest). Instrumen tes yang digunakan dalam uji lapangan berbentuk tes pilihan ganda. Berdasarkan hasil tes, untuk memperoleh gambaran efektivitas penerapan modul sebagai model final, maka dilakukan dengan membandingkan hasil skor post-test (X1) dan skor pre-test ( X2).

Berdasarkan hasil uji $\mathrm{t}$ di atas, dengan harga thit $=27.859$ dan harga ttab $=2,052$ di mana harga sig. $(2$ - tailed $)<0,05$ berarti tolak Ho pada $\alpha=0,05$, maka rata-rata skor post-test dan skor pre-test berbeda secara signifikan. Berdasarkan intepretasi hasil uji t di atas, maka dari hasil uji lapangan dapat diperoleh kesimpulan bahwa penerapan modul belajar mandiri studi Islam berwawasan deradikalisasi pemahaman agama memberikan pencapaian hasil belajar yang lebih tinggi setelah mahasiswa menggunakan modul tersebut. Berdasarkan hasil pre-test dan post-test dalam uji lapangan dapat dikatakan bahwa modul belajar mandiri studi Islam berwawasan deradikalisasi pemahaman agama bagi mahasiswa Fakultas Sains dan Teknologi UIN Syarif Hidayatullah Jakarta ini efektif untuk diterapkan.

\section{Pembahasan}

1. Pencegahan radikalisme pemahaman agama bagi mahasiswa di Fakultas Sains dan Teknologi UIN Syarif Hidayatullah Jakarta

Perguruan tinggi dewasa ini menghadapi tantangan besar dalam menghadapi gejolak radikalisme atas nama agama. Dalam upaya menyebarkan ideologinya kelompok-kelompok radikal menggunakan berbagai cara yang sulit untuk dilacak, termasuk menggunakan metode sel. Metode inilah disebut Lorne L. Dawson dalam Nasih, dkk (2014: 129) dengan sistem penyebaran yang bersifat interpersonalisme Sistem ini menyebar secara personal ke personal lain secara masif, sehingga pola geraknya sulit dilacak.

Meskipun demikian hasil studi pendahuluan ditemukan gambaran bahwa upaya pencegahan radikalisme pemahaman agama yang telah berjalan di Fakultas Sains dan Teknologi UIN Syarif
Hidayatullah Jakarta belum sistemik dan belum relevan dengan kebutuhan mendasar agar mahasiswa tidak menjadi korban infiltrasi radikalisme atas nama agama. Mata kuliah pengantar studi Islam belum memberikan pembekalan yang bersifat metodologis cara memahami ajaran Islam tanpa radikalisme, ketersediaan sumber belajar yang berwawasan deradikalisasi belum tersedia, lebih banyak bahan belajar yang berkaitan dengan kebutuhan perkuliahan sesuai prodi dan fakultas.

Terjadinya kerentanan pemahaman keberagamaan radikal di kalangan mahasiswa UIN Jakarta tidak dapat dipisahkan dengan fakta terjadinya perubahan iklim kehidupan kampus yang lebih terbuka pasca Reformasi politik 1998. Longgarnya kegiatan kemahasiswaan di kampus telah menjadikan perguruan tinggi, termasuk UIN Jakarta, sebagai ajang kontestasi berbagai kelompok dan aliran keagamaan yang semakin beragam.

Selain itu, transformasi IAIN Jakarta ke UIN Jakarta yang ditandai dengan munculnya fakultasfakultas non-keagamaan, seperti telah disebutkan di awal, diikuti dengan perubahan latar belakang demografi sosial-ekonomi dan keagamaan para mahasiswa. Di beberapa fakultas umum, persentase mahasiswa dengan latar belakang pesantren dan sekolah Islam atau madrasah merosot tajam. Pergeseran ini mungkin juga merupakan salah satu faktor yang turut memengaruhi perkembangan perilaku dan paham keagamaan baru para mahasiswa yang menjurus pada radikalisme di lingkungan UIN Jakarta pada saat ini, (Mubarak, 2013: 213-214).

Dampak kerentanan mahasiswa terhadap radikalisme agama cukup besar bagi masa depan profesi mahasiswa. Sebagaimana hasil hasil penelitian Lembaga Kajian Islam dan Perdamaian (LAKIP) yang melibatkan 590 dari total 2.639 guru Pendidikan Agama Islam (PAI) dan 993 siswa Muslim dari total 611.678 murid SMA se-Jabodetabek juga mengalami kerentanan radikalisme agama. Menurut LAKIP, kerentanan radikalisme pemahaman agama pada guru berlangsung sejak lama. Jika upaya pencegahan radikalisme tidak dilakukan sejak dini, maka sangat dimungkinkan mempengaruhi profesi saat menjadi alumni.

Radikalisme atas nama agama merupakan bentuk lampu merah bagi perguruan tinggi. Konsekuensinya, perguruan tinggi perlu memainkan peran startegis untuk menangkal radikalisme, karena bukan hanya membahayakan mahasiswa, namun juga berdampak negatif bagi penyelenggaraan pendidikan. Efek radikalisme bukan hanya personal, 
namun juga publik. Menurut Rizal Sukma dikutip Fanani (2013: 5) "Radicalism is only one step short of terrorism". Radikalisme kadangkala bisa berubah menjadi terorisme, meski tak semua berakhir menjadi teroris. Pada umumnya, para teroris yang banyak melakukan tindakan destruktif dan bom bunuh diri mempunyai pemahaman yang radikal terhadap berbagai hal, terutama soal keagamaan.

Menurut Golose dikutip Karwadi (2014: 147) kerentanan terhadap radikalisme tak bisa dibiarkan, namun perlu dilakukan langkah prefentif yaitu (a) melakukan counter terrorism, terutama bagi kelompok yang sudah teridentifikasi kerentanan tumbuhnya teroris cukup tinggi; (b) mencegah proses radikalisasi (c) mencegah provokasi penyebaran kebencian dan permusuhan antar umat beragama, (d) mencegah masyarakat dari indoktrinasi, (e) meningkatkan pengetahuan masyarakat untuk menolak terorisme (f) memperkaya khazanah atas berbagai faham.

Upaya deradikalisasi di perguruan tinggi Islam merupakan konsekuensi. Radikalisme tidak seharusnya didekati dengan cara represif, namun perlu dilakukan antisipatif dan prefentif melalui perubahan paradigma pemahaman keagamaan. Penguatan perspektif keislaman yang komprehensif bagi mahasiswa melalui penyediaan bahan belajar mandiri yang berwawasan deradikalisasi merupakan bentuk peletakan fondasi agar mahasiswa tidak terjebak dan terinfiltrasi radikalisme.

2. Model Perancangan Modul Bahan Belajar

Mandiri Studi Islam Berwawasan Deradikalisasi Pemahaman Agama.

Model merupakan sesuatu yang menggambarkan adanya pola pikir. Sebuah model biasanya menggambarkan keseluruhan konsep yang saling berkaitan. Menurut Morisson, Ross dan Kemp sebagaimana dikutip Pribadi ( 2009: 86) model desain sistem pembelajaran akan membantu perancang dalam memahami teori dengan lebih baik dan menerapkan teori tersebut untuk menciptakan aktifitas pembelajaran yang efektif dan efisien.

Berdasarkan kajian pustaka, membandingkan model pengembangan yang tersedia, kemudian peneliti memilih Model Pengembangan Instruksional (MPI) sebagai acuan pengembangan bahan belajar mandiri. Pada kedua langkah MPI yaitu menyusun strategi dan pengembangan bahan instruksional diintegrasikan pemikiran The Fifth Discipline dari Peter Senge, mulai berpikir sistem, belajar tuntas, model mental, visi bersama serta belajar beregu. Kelima dimensi dari Peter Senge tersebut dipadukan secara utuh untuk mewarnai kerangka berfikir pengemasan dan strategi dalam bahan belajar mandiri studi Islam berwawasan deradikalisasi pemahaman agama.

The fifth discipline merupakan teori organisasi belajar, namun kerangka berfikir the fifth discipline memiliki kontribusi besar jika digunakan sebagai pendekatan dalam pengemasan pesan dan strategi instruksional bahan belajar mandiri studi Islam berwawasan deradikalisasi pemahaman agama. Karena, orang menjadi radikal itu, bukan karena faktor agama, tetapi cara memahami ajaran agama yang ahistoris, sehingga seseorang dapat dikategorikan sebagai radikal.

Menurut Amin Abdullah sebagaimana dikutip Nurikhwan \& Muttaqin (2013: 11) pendekatan teologik semata dalam studi Islam hanya akan melahirkan "truth claim" dalam arti menekankan pada monopoli kebenaran dengan semboyan 'right or wrong is my country'. Kehilangan atmosfir historis setiap pemikiran keagamaan (baca keislaman) menjadikan pendekatan doktrinal-teologis atau doktrinal-normatif bermasalah dengan perjumpaan dan pergumulan dengan masyarakat multireligius dan multikulutural,

Model Pengembangan Instruksional (MPI) dengan kombinasi The fifth discipline karya Peter Senge pada langkah pengemasan bahan belajar mandiri dan menyusun strategi instruksional relevan dengan kebutuhan studi Islam kontemporer, hal ini dikarenakan; (1), kerangka berpikir sistem merupakan paradigma studi keislaman kontekstual.

Radikalisme tumbuh salah satu faktor utamanya karena dominannya pendekatan parsial dalam memahami ajaran agama, dan deradikalisasi meniscayakan pendekatan sistem dalam memahami ajaran agama; (2), menggali ajaran Islam tanpa batas; dengan membandingkan pandangan, karya tafsir, mereview pemikiran merupakan bagian dari kebutuhan memahami ajaran Islam secara tuntas, bukan penggalan, sehingga disiplin mastery learning relevan dengan studi Islam. (3), potret mental model cukup mempengaruhi terhadap pemahaman atas ajaran agama. Seringkali pemeluk agama tidak bisa membedakan antara wilayah agama dengan pemikiran keagamaan. Inilah yang mempengaruhi pemahaman atas ajarana agama, sehingga aspek mental model relevan dengan studi Islam; (4), setiap agama dipastikan memiliki visi besar, yaitu sebagai rahmat.

Islam merupakan agama rahmat untuk semua, sehingga visi besar itu harus menjadi pengikat dasar dalam memahami ajaran Islam. Ketika terdapat 
pemahaman atas ajaran agama yang menegasikan visi besar, maka perlu dikaji secara mendalam, apakah suatu ayat atau hadits yang dimaksud bersifat kasuistik-kondisional atau universal, sehingga dapat dipahami secara proporsional; (5), team learning merupakan metode yang mentradisi dalam kajian keislaman sejak era Nabi Muhammad, Saw sehingga team learning karya Peter Senge cukup relevan agar mahasiswa terbiasa berdebat, mengkritisi, mereview dan berbagi pandangan tentang perspektif keislaman dari berbagai sumber, sehingga tidak mudah terindoktrinasi ideologi menyimpang.

3. Merancang Modul Bahan Belajar Mandiri Studi Islam Berwawasan Deradikalisasi Pemahaman Agama.

Perancangan sumber belajar dalam bentuk modul merupakan seperangkat prosedur yang dilakukan secara sistematis untuk melaksanakan pengembangan sistem belajar. Menurut M Atwi Suparman (2004: 37) pengembangan instruksional sebagai suatu proses yang sistematis dalam mengidentifikasi masalah, mengembangkan bahan dan strategi instruksional, serta mengevaluasi efektifitas dan efisiensinya dalam mencapai tujuan instruksional.

Modul belajar mandiri studi Islam berwawasan deradikalisasi pemahaman agama ini dirancang menggunakan langkah sistematis sesuai prosedur terpilih, agar hasilnya berorientasi pencapaian tujuan instruksional. Model Pengembangan Instruksional (MPI) dipilih oleh peneliti dikarenakan memiliki komponen yang lengkap dan sistematis. MPI cenderung berorientasi untuk keperluan praktis daripada teoritis. Dengan demikian, berkesesuaian dengan karakteristik bahan belajar mandiri yang cenderung praktis dan spesifik, apalagi semangat dari modul ini untuk menyelesaikan masalah yang sangat spesifik yaitu radikalisasi atas nama agama. Hal ini sesuai dengan sifat MPI yang secara konseptual cocok untuk program yang sepesifik dan khusus.

Modul studi Islam berwawasan deradikalisasi pemahaman agama ini dikemas dalam bentuk bahan belajar mandiri dengan memperhatikan karakteristik mahasiswa sebagi calon pengguna serta mengacu pada pendekatan sistem yang terdiri dari beberapa tahapan kegiatan yang tersusun secara sistematis yaitu tahap mengidentifikasi, mengembangkan, mengevaluasi dan merevisi. Setelah menetapkan MPI sebagai model pengembangan pembelajaran yang tepat untuk mengembangkan desain paket pelatihan, maka ada 3 langkah yang dilakukan, yaitu: tahap identifikasi, tahap mengembangkan, tahap mengevaluasi dan merevisi.

Mengingat faktor distorsi pemahaman agama merupakan salah satu pemicu munculnya radikalisme, maka menghadirkan modul sumber belajar yang berorientasi deradikalisasi merupakan jawaban atas masalah. Menurut Mark Dechesne (2012: 2-4) pada dimensi horisontal terdapat 2 aspek yaitu "endogeneous", berkaitan dengan perubahan pemikiran dan perilaku yang diprakarsai sendiri dan aspek "exogeneous" berkaitan perubahan pemikiran/ perilaku radikal yang disebabkan oleh pengaruh eksternal. Dengan demikian, upaya moderasi terhadap pemikiran radikal perlu dilakukan upaya menciptakan suatu keadaan agar seseorang dapat terbuka terhadap sudut pandang alternatif yang moderat.

Pada level perguruan tinggi, pilihan "pendekatan ideologi" melalui highlighting religion's emphasis on peace adalah strategi yang mendasar (Rana, 2011:1). Output dari deideologisasi tersebut yaitu perubahan cara berfikir dari penganut atau berpotensi terjebak ideologi radikal, selanjutnya menerima nilai-nilai atau ideologi pemahaman ajaran Islam mainstream.

Dengan demikian, modul belajar mandiri studi Islam berwawasan deradikalisasi pemahaman agama diproyeksikan untuk mencegah, menetralisir dan mengubah pemahaman yang radikal atas ajaran agama. Jika radikalisme pemahaman agama tidak diitervensi, dampak yang ditimbulkan cukup kompleks, baik bagi Islam maupun perguruan tinggi. Jika tidak dilakukan intervensi pencegahan dan pelurusan atas kerentanan radikalisme pemahaman agama di kalangan mahasiswa, setidaknya ada 3 dampak negatif yang timbul yaitu implikasi teologi, politik dan psikologis (Umar, 2014: 275-320).

Sejatinya, kerentanan radikalisme atas nama agama, memang telah menjadi gejala bukan hanya mahasiswa Islam, namun pemeluk agamaagama, seperti Kristen, Yahudi, Hindu dan Budha. Berdasarkan penelusuran historis, fenomena radikalisme merupakan gejala yang terjadi di hampir semua agama, baik yang dapat menimbulkan kekerasan agama ataukah tidak. Kekerasan di dalam agama Hindu dapat dijumpai dalam kasus kekerasan agama di India Selatan, yaitu antara kaum Sikh haluan keras dengan Islam. Di Israel juga dijumpai kekerasan agama antara Kaum Yahudi Ultra dengan umat Islam. Di Jepang juga dijumpai kekerasan agama Shinto dalam bentuk penyimpangan agama yang mencederai lainnya. Demikian pula di agama Kristen seperti halnya yang terjadi di Amerika Serikat 
dan juga belahan Eropa lainnya. Di dalam Islam juga dijumpai kekerasan agama seperti terjadinya berbagai teror baik yang langsung maupun tidak langsung mencelakai orang lain (Sodiq, 2015: 1594).

Dalam banyak kasus radikalisme keagamaan menimbulkan beragam aksi. Mereka bukan hanya menteror apa yang mereka klaim sebagai musuh, tapi juga telah menimbulkan hentakan psikologis yang sangat dahsyat, terutama bagi mereka yang merasa agamanya telah disalah maknai. Satu hal yang pasti bahwa kelompok radikal tidak pernah dominan dalam sejarah Islam. Ia tidak pernah mendapat simpati dan selalu marginal dalam perjalanain sejarahnya.

Dalam konteks Indonesia, gerakan radikalisme atas nama agama juga berupaya menyebarkan ideologi mereka ke setiap sektor termasuk kampus. Kampus dipilih sebagai salah satu sasaran penyemaian ideologi karena disitu terdapat banyak mahasiswa yang dilihat dari segi mentalitas tergolong masih labil dan mudah terpengaruh. Kaum muda dianggap berpotensi dalam meneruskan gerakan negara Islam, karena selain berpendidikan pemahaman mereka terhadap Islam juga relatif dangkal.

Implikasi psikologis dari radikalisme pemahaman keagamaan diantaranya; (1), munculnya Islam phobia (ketakutan terhadap Islam); (2), menimbulkan perasaan tidak nyaman ketika berinteraksi dengan umat Islam; (3), perasaan negatif atas Islam, berpotensi menular kepada anak keturunan; (4), melemahkan minat agama lain untuk berinteraksi dengan Islam; (5), menimbulkan perilaku protektif yang berlebih terhadap Islam; (6), mengganggu hubungan dan produktifitas umat Islam secara umum

Kondisi tersebut, menjadikan Islam tereduksi nilai-nilai keagungannya. Kesyahduan beragama berubah menjadi keberingasan, semangat pencerahan tergantikan oleh, nilai kesucian jihad, berubah menjadi keganasan yang penuh heroik. Keberagamaan yang sejatinya dikembangkan di atas kecerdasan emosi dan nalar argumentatif bukan kekuatan destruktif, berwujud pentungan dan sejenisnya yang tak akan memberi dampak penyadaran dan transformasi nilainilai moral luhur Islam.

Oleh karena itu, perspektif deradikalisasi dalam produk hasil pengembangan modul berwawasan deradikalisasi pemahaman agama ini bukan dimaksudkan sebagai upaya untuk menyampaikan "pemahaman baru" tentang Islam dan bukan pula pendangkalan akidah, tetapi sebagai upaya meluruskan pemahaman tentang apa dan bagaimana Islam serta mencegah munculnya radikalisme atas ajaran Islam.

Efektifitas modul bahan belajar mandiri studi Islam berwawasan deradikalisasi pemahaman agama untuk peningkatan kemampuan mahasiswa memahami ajaran Islam secara komprehensif untuk mencegah radikalisme. Menurut Wotruba dan Wright dalam Miarso (2009: 536) salah satu indikator keefektifan belajar adalah hasil belajar siswa. Peningkatan nilai hasil belajar antara sebelum diberikan modul dengan sesudah diberikan modul sebagai bahan belajar menunjukkan bahwa bahan belajar yang telah diberikan kepada pengguna berdampak positif.

Selain hasil belajar siswa, indikator lain untuk menunjukkan kefektifan menurut model evaluasi Kirkpatrick mencakup; reaksi, belajar, perilaku dan hasil (Wolf, 2006: 8). Reaksi mahasiswa dapat diekspresikan melalui jawaban dari suatu pernyataan yang menunjukkan bahwa siswa lebih menyukai sesuatu hal daripada hal lainnya. Dapat pula dilihat melalui partisipasi dalam suatu aktivitas dan cenderung memberikan perhatian yang lebih besar terhadap obyek tersebut.

Secara keseluruhan, baik dalam uji coba perorangan, uji coba kelompok kecil dan uji coba lapangan, modul belajar mandiri studi Islam berwawasan deradikalisasi pemahaman agama dapat diterima dengan baik. Kejelasan materi pembelajaran, dampak bagi pengguna, kelayakan dan sikap pengguna, kemenarikan modul, durasi waktu pembelajaran, penguasaan materi pembelajaran, kesesuaian penggunaan ilustrasi, kesesuaian evaluasi dengan materi, kelayakan produk pengembangan dan kemutakhiran materi produk pengembangan diterima dan diapresiasi dengan baik sehingga layak digunakan.

Keterterimaan tergambar bahwa tingkat penerimaan subyek uji coba pada tiga tingkatan berada pada kategori sangat baik. Uji coba Perorangan mencapai 89, 23\%, selanjutnya Uji coba Kelompok Kecil 90,82\% sementara Uji Coba Lapangan 91,28\%. Artinya, berdasarkan tanggapan hasil uji coba tersebut dapat ditarik suatu pernyataan bahwa produk pengembangan modul belajar mandiri studi Islam berwawasan deradikalisasi pemahaman agama sudah efektif, dapat diterima dan dapat digunakan sebagai sumber belajar baru bagi mahasiswa.

Di sisi lain, dilihat dari hasil belajar, adanya perubahan perilaku pengguna menunjukkan bahwa proses belajar memiliki dampak. Sebagaimana hasil uji $t$, dengan harga thit $=27.859$ dan harga ttab $=$ 2,052 di mana harga sig. $(2$ - tailed $)<0,05$ berarti 
tolak Ho pada $\alpha=0,05$, maka rata-rata skor posttest dan skor pre-test berbeda secara signifikan. Berdasarkan intepretasi hasil uji $t$ di atas, maka dari hasil uji lapangan dapat diperoleh kesimpulan bahwa penerapan modul belajar mandiri studi Islam berwawasan deradikalisasi pemahaman agama memberikan pencapaian hasil belajar yang lebih tinggi setelah mahasiswa menggunakan modul tersebut.

Perubahan pemikiran keagamaan ke arah positif, dalam konteks belajar keagamaan merupakan sebuah keberhasilan. Menurut perspektif behavior modification, bahwa cara berfikir yang keliru menyebabkan masalah perilaku dan emosi. Jika terdapat proses berfikir yang keliru termasuk keliru dalam memahami ajaran agama, maka kekeliruan dimaksud harus menjadi target dilakukan perubahan cara berfikirnya. Proses ini dikategorikan sebagai modifikasi behavioral kognitif (Martin \& Pear, 2015: 835-836).

Dalam perspektif psikologi agama, penyimpangan atas nama agama memiliki hubungan antara persepsi seseorang mengenai kepercayaan dan keyakinan. Kepercayaan merupakan tingkat berpikir manusia dalam mengalami proses berfikir yang telah dapat membebaskan manusia dari segala unsurunsur yang terdapat di luar pikirannya. Sedangkan keyakinan merupakan suatu tingkat berpikir yang dilandaskan pada kepercayaan dan keyakinan ajaran agama sebagai penyempurna. Terjadinya penyimpangan atas nama agama, jika terjadi proses penyimpangan dari kedua tingkat berpikir tersebut, sehingga dapat memberi kepercayaan dan keyakinan baru pada seseorang atau kelompok, (Jalaluddin, 2015: 237).

Berdasarkan hasil penelitian Elis Yudianingsih dengan berpijak pada teori Kohlberg ditemuan bahwa semakin besar tingkat penalaran moral yang dimiliki, maka akan semakin tinggi pula komponen karakter baik yang dimiliki. Artinya, semakin tinggi pemahaman terhadap ajaran agama sebagai sumber moral untuk menilai hal yang baik dan buruk, maka karakter yang muncul dalam dirinya semakin baik (Yudianingsih, 2015: 321).

Berdasarkan pandangan ahli di atas baik dari perspektif psikologi agama, modifikasi perilaku dan penelitian tentang penalaran moral dimaksud dapat dinyatakan bahwa terjadinya peningkatan pemahaman atas ajaran Islam tanpa radikalisme setelah mahasiswa menggunakan modul belajar mandiri studi Islam berwawasan deradikalisasi pemahaman agama, dapat diprediksi kuat berpengaruh terhadap perilaku mahasiswa, mengingat pemahaman atas ajaran agama memiliki korelasi terhadap keyakinan, sementara keyakinan sangat mempengaruhi terhadap perilaku. Dengan demikian, pemahaman atas ajaran Islam berwawasan deradikalisasi berkorelasi terhadap konstruksi keyakinan dan perilaku keseharian mahasiswa.

Pengembangan modul belajar mandiri studi Islam berwawasan deradikalisasi pemahaman agama memberikan kontribusi sebagai berikut. Pertama, penyediaan sumber belajar yang berwawasan deradikalisasi pemahaman agama dapat menekan infiltrasi radikalisme di kalangan mahasiswa. Kedua, modul memiliki dampak positif bagi khasanah studi Islam berwawasan deradikalisasi pemahaman agama, konsekuensinya pimpinan fakultas perlu menerapkan modul dimaksud sebagai salah satu bentuk strategi pencegahan radikalisme atas nama agama. Ketiga, modul memiliki dampak positif untuk membekali mahasiswa secara metodologis memahami Islam tanpa radikalisme, maka fakultas dan tingkat universitas perlu meningkatkan ketersediaan sumber belajar yang berkonten metodik berwawasan deradikalisasi pemahaman agama.

\section{PENUTUP}

\section{Kesimpulan}

Dari keseluruhan proses penelitian dan pengembangan modul belajar mandiri studi Islam berwawasan deradikalisasi pemahaman agama, maka dapat disimpulkan sebagai berikut. Pertama, hasil identifikasi upaya pencegahan radikalisme pemahaman agama yang telah berjalan di Fakultas Sains dan Teknologi UIN Syarif Hidayatullah Jakarta belum sistemik dan belum relevan dengan kebutuhan mendasar agar mahasiswa tidak menjadi korban infiltrasi radikalisme atas nama agama. Mata kuliah pengantar studi Islam belum memberikan pembekalan yang bersifat metodologis cara memahami ajaran Islam tanpa radikalisme, ketersediaan sumber belajar yang berwawasan deradikalisasi belum tersedia, lebih banyak bahan belajar yang berkaitan dengan kebutuhan perkuliahan sesuai prodi dan fakultas.

Kedua, berdasarkan kajian pustaka, membandingkan model pengembangan yang tersedia, memperhatikan orientasi produk, analisis kebutuhan serta karakteristik pengguna, kemudian peneliti memilih Model Pengembangan Instruksional (MPI) sebagai acuan pengembangan bahan belajar mandiri. Pada kedua langkah MPI yaitu menyusun strategi dan pengembangan bahan instruksional diintegrasikan 
pemikiran The Fifth Discipline dari Peter Senge, mulai berpikir sistem, belajar tuntas, model mental, visi bersama serta belajar beregu. Kelima dimensi dari Peter Senge tersebut dipadukan secara utuh untuk mewarnai kerangka berpikir pengemasan dan strategi dalam bahan belajar mandiri studi Islam berwawasan deradikalisasi pemahaman agama.

Ketiga, proses perancangan modul belajar mandiri studi Islam berwawasan deradikalisasi pemahaman agama diawali dengan identifikasi kebutuhan instruksional dan menuliskan tujuan instruksional umum, melakukan analisis instruksional, mengidentifikasi perilaku dan karakteristik awal mahasiswa, menuliskan tujuan instruksional khusus, menulis tes acuan patokan, menyusun strategi instruksional, mengembangkan bahan instruksional. Dalam pengemasan bahan belajar dan menyusun strategi instruksional diintegrasikan dengan pemikiran The Fifth Discipline dari Peter Senge. Selanjutnya menyusun desain dan melaksanakan evaluasi formatif. Uji formatif terdiri dari uji ahli (ahli desain instruksional, ahli materi dan ahli bahasa), uji one to one, uji kelompok kecil serta uji lapangan. Hasil akhir dari formatif berbentuk sistem instruksional dalam bentuk modul belajar mandiri studi Islam berwawasan deradikalisasi pemahaman agama.

Keempat, hasil uji efektifitas produk melalui coba lapangan ditemukan bahwa produk pengembangan dalam bentuk modul belajar mandiri studi Islam berwawasan deradikalisasi pemahaman agama mampu meningkatkan kemampuan mahasiswa memahami ajaran Islam tanpa radikalisme. Efektifitas produk dibuktikan melalui respon mahasiswa terhadap produk dan hasil belajar mahasiswa yang meningkat, dibuktikan melalui Uji t dengan membandingkan hasil pre test dan post test. Adanya peningkatan pemahaman mahasiswa terhadap ajaran Islam tanpa radikalisme, dapat diprediksi kuat berpengaruh terhadap perilaku mahasiswa, mengingat pemahaman atas ajaran agama memiliki korelasi terhadap keyakinan, sementara keyakinan sangat mempengaruhi terhadap perilaku.

\section{Saran}

Sehubungan dengan pengembangan modul belajar mandiri studi Islam berwawasan deradikalisasi pemahaman agama, peneliti/pengembang perlu menyampaikan saran kepada pihak-pihak terkait, sebagai berikut.

Pertama, saran untuk pimpinan UIN Syarif Hidayatullah Jakarta, terdapat kecenderungan radikalisme pemahaman keislaman di kalangan mahasiswa perlu intervensi solusi secara sistemik dan terstruktur melalui beragam strategi. Penyediaan bahan belajar mandiri studi Islam berwawasan deradikalisasi pemahaman agama hanyalah merupakan salah satu alternatif intervensi, sehingga masih diperlukan strategi terpadu yang saling mengisi dan memperkuat.

Kedua, bagi mahasiswa, mengingat dampak dari modul sangat positif bagi mahasiswa terutama membekali secara metodik untuk pencegahan radikalisme pemahaman agama, maka bagi pengguna disarankan agar menularkan deradikalisasi pemahaman keislaman kepada mahasiswa lain yang belum menggunakan modul dimaksud.

Ketiga, saran untuk peneliti selanjutnya, agar ada penelitian dan pengembangan berikutnya untuk mengembangkan bahan belajar yang berwawasan deradikalisasi pemahaman agama dalam bentuk yang lain, sehingga ketersedian sumber belajar dengan perspektif yang sama semakin variatif.

Keempat, saran untuk Kementerian Agama RI dan Kementerian Riset, Teknologi dan Pendidikan Tinggi RI. Sejumlah penelitian melaporkan bahwa radikalisme benar adanya tumbuh di kalangan mahaiswa. Kondisi ini dapat mengancam proses penyelenggaraan pendidikan di perguruan tinggi, sehingga perlu upaya sistemik dalam pencegahan radikalisme.

Kelima, saran untuk Kementerian Pendidikan dan Kebudayaan RI., dan Kementerian Agama RI, mengingat infiltrasi radikalisme yang diperoleh saat Pendidikan Usia Dini, Pendidikan Dasar dan Menengah cukup berpengaruh terhadap kerentanan radikalisme di kalangan mahasiswa, maka perlu mengembangkan sistem layanan pendidikan yang zero radikalisme dengan berbagai strategi dan pendekatan.

\section{DAFTAR PUSTAKA}

Al-Qurtuby, S. (2000). Jihad membangkitkan Islam progresif. Semarang: Borobudur Indonesia Publishing.

Borg, W. R., \& Gall, M. D. (1983). Educational research: An introduction. Fifth Edition. New York: Longman.

Dechesne, M. (2012). Deradicalization: Not soft, but strategic. Leiden: The Hague Center for Terrorism and Counterterrorism (CTC) University of Leiden.

Fanani, A. F. (2013). Fenomena radikalisme di kalangan kaum muda dalam menghalau radikalisme kaum muda: Gagasan dan aksi. eds. Ahmad Syafii Maarif et al. Jakarta: Maarif Institute. 
Fikri, Z. (2013). Narasi deradikalisasi di media online Republika dan Arrahmah. Jurnal Lektur Keagamaan, Vol. 11 No. 2.

Ghafur, A. (2014). Jejak radikalisme pemahaman agama di perguruan tinggi. Ciputat: Cendekia Press.

Jalaluddin. (2015). Psikologi agama: Memahami perilaku dengan mengaplikasikan prinsip-prinsip psikologi. Jakarta: Raja Grafindo Persada.

Jamaluddin. (2015). Radikalisme pemahaman agama: masalah dan solusinya. Depok: Mitra Madani.

Karwadi. (2014). Deradikalisasi pemahaman ajaran Islam. Jurnal At-Tahrir, Vol 4.

Martin, G.,\& Pear, J. (2015). Modifikasi perilaku: makna dan penerapannya. Yogyakarta: Pustaka Pelajar.

Miarso, Y. (2009). Menyemai benih teknologi pendidikan. Jakarta: Kencana Predana Media Group.

Mubarak, M. Z. (2013). "Pemikiran dan perilaku keberagamaan mahasiswa UIN Syarif Hidayatullah Jakarta" dalam menghalau radikalisme kaum muda: Gagasan dan aksi, eds. Ahmad Syafii Maarif et al. Jakarta: Maarif Institute.

Nasih, A. M., dkk. (2013). Pemaknaan dosen agama islam terhadap radikalisasi kehidupan beragama mahasiswa di Malang Indonesia. Jurnal Studi Sosial, No. 2.

Nurikhwan, M.,\& Muttaqin, A. (Editor). (2013). Islam, agama-agama, dan nilai kemanusiaan. Yogyakarta: CISForm.

Pribadi, B. A. (2009). Model desain sistem pembelajaran. Jakarta: Dian Rakyat.

Rana, M. A. (2011). Swat de-radicalization model: prospects for rehabilitating militants. Conflict and Peace Studies, Volume 4, (2.).
Rapik, M. (2014). Deradikalisasi faham keagamaan: Sudut pandang Islam. Jurnal Inovatif, Vol. VII No. II ..

Senge, P. (2000). Afifthe displine, schools that learn. New York: Doubleday.

Sodiq, M. F. (2015). Radikalisme dalam Islam antara pelabelan dan konstruksi sosiologi. Jurnal GEMA, No. XXVII/ 49.

Suparman, M. A. (2004). Desain instruksional. Jakarta: Universitas Terbuka.

Suparman, M. A. (2012). Desain instruksional modern. Jakarta: Erlangga.

Umar, N. (2014). Deradikalisasi pemahaman Al-Qur'an dan hadits. Jakarta: Elex Media Komputindo, 2014.

Usman. (2014). Model deradikalisasi narapida terorisme studi perbandingan deradikalisasi di Yaman, Arab Saudi, Singapura, Mesir dan Indonesia. Jurnal Inovatif, Volume VII No 2.

Winarni, S. (2013). Integrasi Pendidikan Karakter dalam Perkuliahan. Jurnal Pendidikan Karakter,Tahun III, No 1.

Wolf, P. (2006). Handbook for curriculum assesment. Canada: Guelph University.

Yudianingsih, E., dkk. (2015). Analisis penalaran moral menggunakan Defining Issue Test (DIT) dan soal isu-isu sains pada tema hidrosfer. Materi Simposium Nasional Inovasi dan Pembelajaran Sains, Bandung, 8 dan 9 Juni.

Yurisaldi, A. (2011). Jangan biarkan anak menjadi teroris: Tinjauan ilmu kedokteran saraf model, Islam moderat dan budaya Jawa. Yogyakarta: Titano.

Zarkasy, J.,\& Al-Ashar, T. (2014). Radikalisme agama $\mathcal{E}$ tantangan kebangsaan. Jakarta: Direktorat Jenderal Bimas Islam Kementerian Agama RI. 